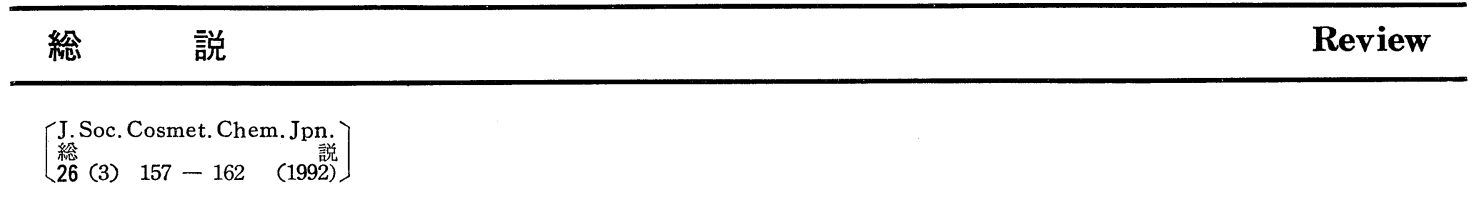

\title{
医薬品におけるエマルションの利用
}

\author{
広田貞雄
}

静岡県立大学薬学部

\section{Use of Emulsion in Drug Products}

\author{
Sadao Hirota \\ School of Pharmaceutical Sciences, University of Shizuoka. $\dagger$
}

\section{1. はじめに}

医薬品に怙けるェマルションを外用剤, 内服用 剤, 注射剂に分けて、それぞれについて，その利 用の現況について述べてみたい。

\section{2. 外用剤としてのエマルション}

外用剂の製造技術上の問題点は基本的には化粧 品エマルションと変わらないが, 外用剤エマルシ ョンでは，主薬が皮下組織に吸収されることを目 的としているところが化粧品と大きく異なってい る。主薬の経皮吸収促進は外用剂の重要な課題で あるが，化粧品では何らかの成分が皮下組織，こ とに血液中に吸収されることは望ましいとは考穴 られないであろう。経皮吸収促進のために外用剂 に特いては角質層の破壊はやむを得ないことと考 えられている。角質層破壞剤の使用や密封療法

(Occlusion Dressing Therapy, ODT : 適用 した外用剂の上からパラフィンフィルムで患部を 覆い, 角質層を水和させて薬物吸収を促進する療 法）の採用が行われている。医療の目的から一時 的には許されるが, 恒常的な使用が前提となる化 粧品には好ましいとは考劣られないであろら。も ら一つ, 外用剤に特有の要件は, 使用乙得る乳化

$\dagger$ 个422 静岡県静岡市矢田52-1; 52-1 Yada, Shizuoka-shi 422 Japan
剤の種類に厳しい制約が存在することである。主 要各国の局方に収載せれている乳化剂のほか使用 前例のある乳化剤を使うことができるが，化粧品 に使用可能な乳化剂に比してその種類はかなり限 定される。使用前例のある乳化剂も制限強化の方 向にある。

\section{3. 経ロ剤としてのエマルション}

内服用エマルションに拈いて使用可能な乳化剂 の種類は外用剂に使用可能な乳化剂より更に少な い。小腸粘膜を覆う microvilli は乳化剤により 容易に脱離する。胆汁による microvilli の脱離 は生理的現象であり, microvilli の新生と均衡を 保っている。しかし, ェマルションの内服による 乳化剂の一時的增加は, この均衡を不可逆的に破 ることになり，その修復にかなりの時間が費やさ れることになる。日本薬局方には土マルション製 剤は収載されていない。英国薬局方には流動パラ フィンを配合したエマルションが内服用下剂とし て収載されている。流動パラフィンは胆汁の過唾 の分泌を促すが，用いられている乳化剂も消化管 粘膜の脱離を招き, 緩下剂として働いていると見 るべきであろら。

\section{4. 注射剤としてのエマルション}

1960年代より重症患者に対するエネルギー補給 の目的で大豆油の $\mathrm{O} / \mathrm{W}$ 型マイクロエマルション 
の静脈投与が実施されるようになった。乳化剤 として, レシチン, dialkyloyl phosphatidyl ethanolamine (PE), polyoxyethylene hydrogenated castor oil derivative (HCO 60), Tween 類が使用実績をもっている。乳化剂とし て優れたものは赤血球脂質膜の可溶化による溶血 を招くばかりでなく, 全身のマスト細胞の賦活に よるアナフィラキシーショックをはじめとする過 剰免疫反応の原因になる。直径 $1 \mu \mathrm{m}$ 以上の大き さの油滴は肝臓, 脾蔵, 肺臓などに分布する細網 内皮系（主に異物除去機能を持つ免疫細胞である マクロファージを豊富に持つ血管系：reticuloendothelial system : RES) に捕捉され速やか に血中から消失し，エネルギー産生に寄与しない ばかりか, マクロファージの過度の賦活によっ て，好ましくない免疫反応を引き起こすことにな る1)。

マイクロエマルションとして，ミセル可溶化系 （大豆油によって膨閏した界面活性剂ミセル）は 界面化学的安定性が熱力学的に保証される点では 好むしいが，これを実現するためには大量の水溶 性界面活性剤が必要であり, 上述のような安全性 の要求を満たさない。ミセル可溶化系によらない マイクロエマルション, すなわち微量の界面活性 剤により機械的微細化によって作られたマイクロ エマルションは大きな界面エネルギーを内蔵する ため, その界面化学的安定性の保証はかなり困難 である。レシチンによって代表されるリン脂質を 乳化剤とし，マントンガウリン型あるいはマイク ロフルイダイザー型のよらな高圧噴射乳化機によ って微細化したマイクロエマルションが, 乳化状 態の安定性と薬学的安全性の両方の要求を満足す るエネルギー補給用の静脈注射剂として広く実用 に供されている。生理活性を持たないリン脂質は 生体適合性 (biocompatibility), 生分解性 (biodegradability) を有する優れた乳化剤であるが， リゾレシチンや PAF (platelet activating factor : 血小板凝集因子)（図一-1）またエンドトキ シン（図-2）のよらな強い生理活性を持つ脂質が 混在すると静注用マイクロエマルションの乳化剂 としては不適当となる。

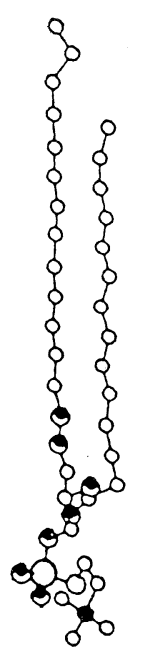

レシチン

ゾレシチン

PAF (Platelet activatging factor)

図-1 リン脂質の分子構造

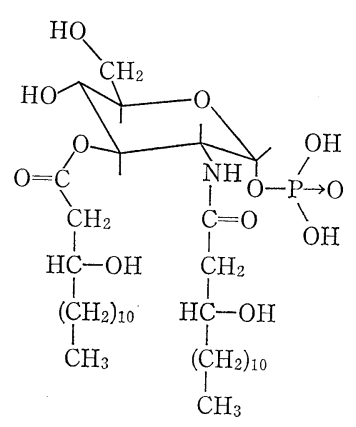

Lipid $\mathrm{x}$

図-2 エンドトキシンの一例

レシチンの分子分散濃度は極めて低く $\left(10^{-9} \mathrm{M}\right.$ のオーダー), ミセルを形成する可能性はほとんど ないので, 細胞傷害性が極めて低い。レシチンを 乳化剂とするマイクロエマルションは優れた薬物 担体として脂溶性薬物の DDS として利用されつ つある2) 5)

レシチンによる乳化系はレシチンによるリポソ ームと共存することが明らかにされた6)。現在, 実用に供されている静注用マイクロエマルション では油水界面単分子膜形成必要量に比して大過剩 のレシチンが処方されているので, 系中にリポソ ームが共存する可能性は大きい。リポソームは 


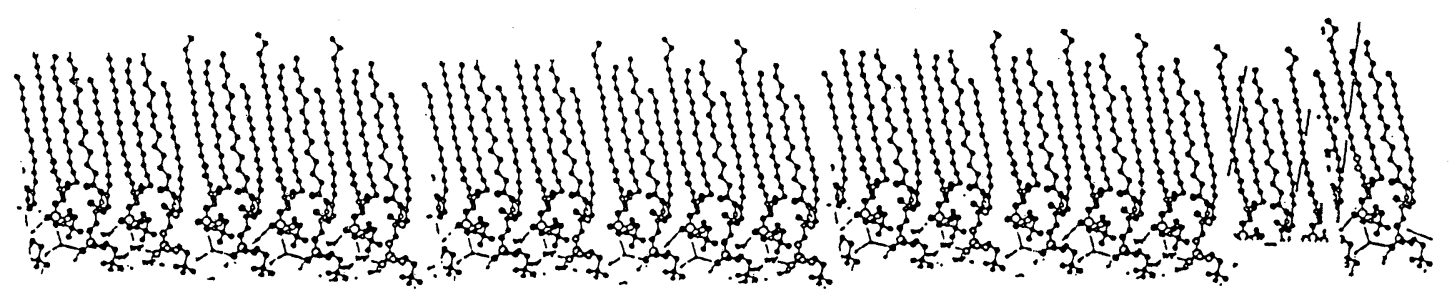

水 相

油水界面の単分子膜（油滴表面のレシチンの飽和吸着数）

水 相

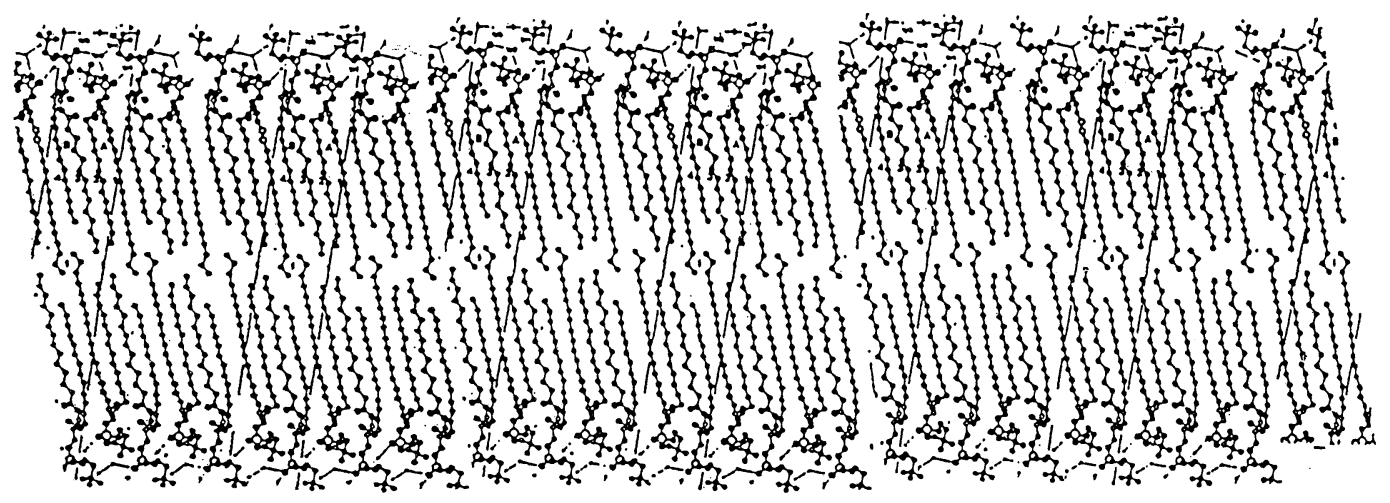

図-3 レシチン膜の構造

図-3に示すよらな脂質 2 重膜（ラメラ）によって 包まれた内水相を有する小胞体である。レシチン 単分子膜（図-3）によって包まれた大豆油滴表面 はりポソーム表面と極めて類似した構造を持って いると考えて良い。

リン脂質膜表面を蛋白, 糖蛋白, 糖脂質で被覆 することによる生物活性化の研究はリポソームを 素材として非常な進歩を遂げた7)。リポソームと マイクロエマルションの共存の事実を考えるとリ ポソーム研究で得られたその成果はレシチン一大 豆油乳化系に和いても再現される可能性が大き w。

これらのマイクロエマルション粒子は静注後マ クロファージ $(\mathrm{M} \psi)$ に捕捉され, 病変部位に集ま る性質を有するので, 効果的な薬物送達を実現す る事が出来る。ここに，化粧品製造に和いて培わ れた界面化学的技術が最大限に発揮され得るので
ある。マイクロエマルション粒子の $\mathrm{M} \psi$ による捕 捉は必然的に免疫系細胞全体の賦活を招来する。 免疫系の過度の賦活は好ましいものではないが, 一方, 生体の自然防御機構を発動させる可能性が ある。その利点を最大限に引きだそうとする試み が，主としてリポソームを素材として展開されて きた。リポソームとマイクロエマルションの共存 の事実を考光ると、リポソーム研究で得られた成 果は，そのままマイクロエマルションに適用され 得ると考えられる。

多くの細胞種の細胞壁ペプチドグリカンは免疫 応答調節作用（immunomodulation）をはじめ 多彩な生物活性を持つ。その生物活性発現に必要 な最小構造単位が MDP (N-acetylmuramyl Lalanyl D-isoglutamine) であることが Ledler ら () と谷ら $^{91}$ によって，それぞれ独立に報告さ れた。 
MDP（図-4）は immunomodulator として の活性は高いが，大きな水溶性のため静注すると 投与後速やかに血中から消失し薬効を発揮できな
い。

Brodot, Fidler $ら^{10)}$ は distearoyl phosphatidyl choline (DSPC), dimyristoyl

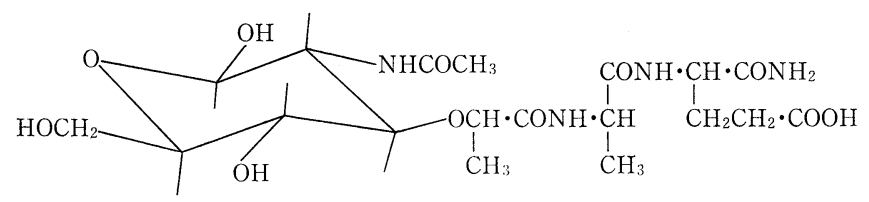

MDP (muramyl dipeptide: $\mathrm{N}$-acetyl muramyl L-alanyl D-isoglutamine)

図-4 MDP

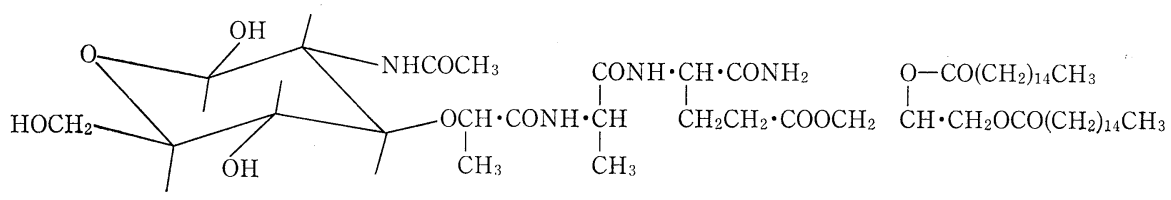

図-5 MDPGDP (MDP-glyceryl dipalmitate)

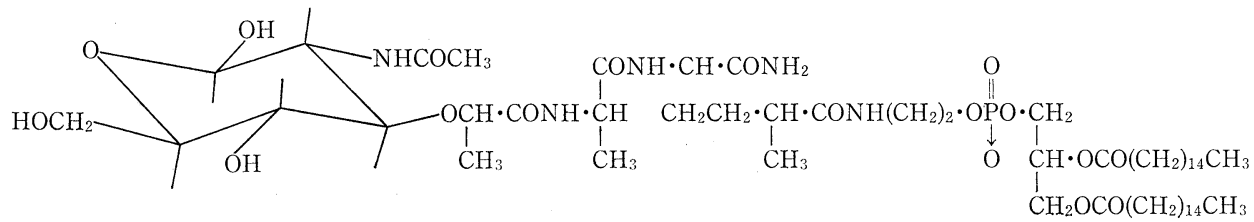

図-6 MTPPE (MDP L-alanyl dipalmitoyl phosphatidyl ethanolamine)

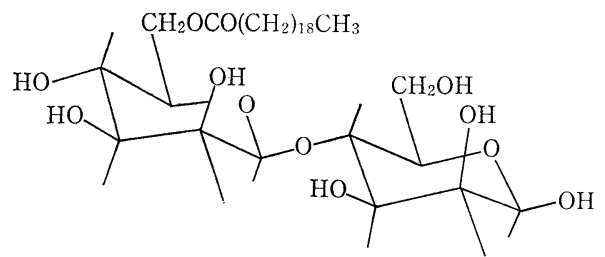

(1) 4-O(6-O-eicosanoly- $\beta$-D-nannopyranosyl) D-nannopyranose

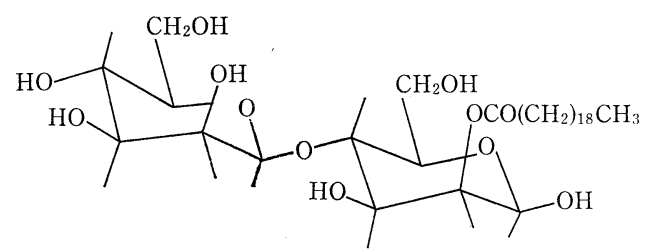

(3) 6-O-eicosanoyl-4-O- $\beta$-D-mannopyranosylD-mannopyranose

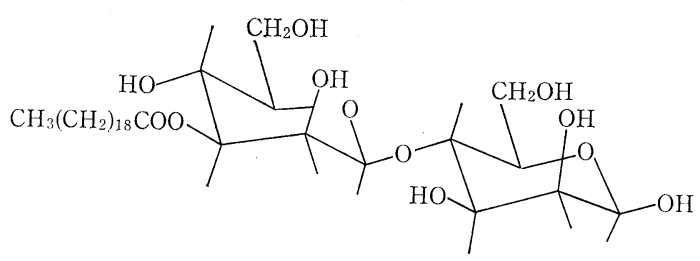

(2) 4-O(3-O-eicosanoyl- $\beta$-D-mannopyrannosyl) D-mannopyranose

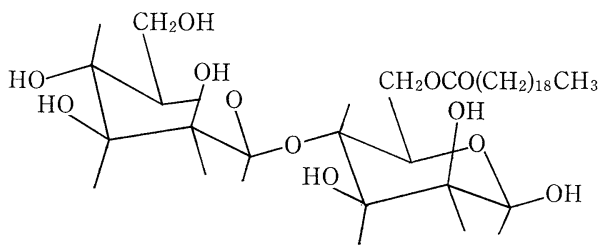

(4) 2-O-eicosanoy1-4-O- $\beta-\mathrm{D}-\mathrm{mannopyranosyl-}$ D-mannopyranose

図-7 mannobiose mono-arachidoyl esters 
phosphatidyl choline(DMPC)よりなるリポソー ム膜にMDP-glycerol dipalmitate(MDPGDP) （図一5）を組み込ませた場合のマウス静注後の体 内分布を検討した。4 時間後, このリポソームの $50 \%$ 以上が肝に分布し，24時間後更に増加する傾 向を示したのに対して，腎，脾，血中への分布は
少なかった。肺では 4 時間後 $13 \%$ に達するが， 24 時間後には殆ど消失していた。彼らはこのマウス から Kuppfer $\mathrm{M} \psi$ を取り出し抗腫瘍活性を測定 乙, 対照無処置 $\mathrm{M} \psi, \mathrm{MDP}$ 単独投与群の $\mathrm{M} \psi$, のいずれに比しても明らかに高い活性を示したこ とを報告している。この MDPGDP 含有リポソ
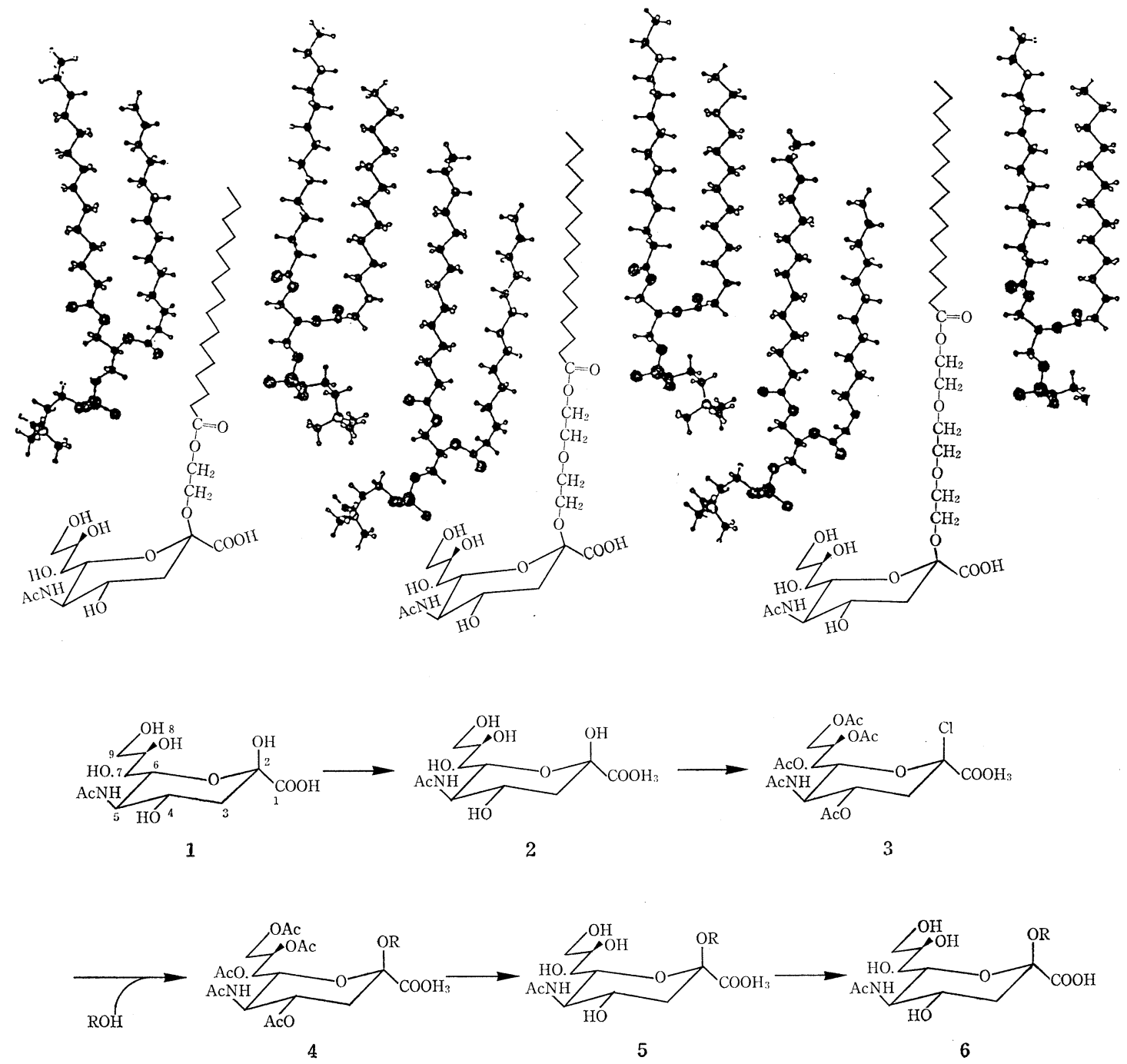

ROH: $\mathrm{C}_{15} \mathrm{H}_{31} \mathrm{COO}\left(\mathrm{CH}_{2}\right)_{2} \mathrm{OH}$

$\mathrm{C}_{15} \mathrm{H}_{31} \mathrm{CO}\left[\mathrm{O}\left(\mathrm{CH}_{2}\right)_{2}\right]_{2} \mathrm{OH}$

$\mathrm{CH}_{3}\left(\mathrm{CH}_{2}\right)_{7} \mathrm{CH}=\mathrm{CH}\left(\mathrm{CH}_{2}\right)_{7} \mathrm{CO}\left[\mathrm{OCH}_{2} \mathrm{CH}(\mathrm{OH}) \mathrm{CH}_{2}\right]_{2} \mathrm{OH}$

図-8 脂質膜表面の糖による修飾 
ームは H59 移植肝癌マウスでも強い in vivo 抗 腫瘍効果を示した。これは肝 Kuppfer $\mathbf{M} \psi$ が活 性化されたためであるといえる。此の実験ではマ ウスに H59 を接種後 3 日後にリポソームの静注 が行われたが，H59 接種量が $5 \times 10^{5} /$ mouse 以 上になると上記の効果は見られなくなってしま う。しかし実験順序を変えて腫瘍接種 3 日前にこ のリポソームを静注しておくと接種量が $5 \times 10^{5}$ / mouse でも抗腫瘍効果が見られた。これは癌の 原発巣が肝以外にあるとき肝転移を予防すること が出来ることを示唆している。

Talmadge ら ${ }^{11)}$ は muramyl tripeptide dipalmitoyl phosphatidyl ethanolamine (MTPPE)（図-6）含有リポソームについて, UV 照 射による皮膚癌マウスで癌細胞の増殖抑制と延命 効果を見ている。このマウス評価系では免疫能が 著しく低下しているが，そのような悪条件に拈い ても MTPPE リポソームは免疫能を復活させ, 増殖抑制と延命がみられた。

$\mathrm{M} \psi$ による脂質粒子の取り込みは粒子径に大き く影響される。粒子径が $100 \mathrm{~nm}$ 以下になると取 り込みが急速に低下する。粒子径の如何に関わら ず $\mathrm{M} \phi$ への取り込みを確実にするために, $\mathrm{M} \psi$ 表 面に存在する mannose recepter pathway を 活用するのは効果的である。われわれは脂質膜に mannobiose の脂肪酸誘導体 (図-7, 図-8) を組 み込ませることによって確実に $\mathrm{M} \psi$ に取り込ま せることが出来ることを見いだした ${ }^{12)} 。$

\section{5.おわりに}

エマルション，とくにレシチンによって乳化さ れたマイクロエマルションの DDS への応用はま だ始まったばかりである。リポソーム研究によっ て示されている成果は殆どすべてマイクロエマル ションにも適用できるものである。その医薬品へ の応用の利益は量りがたい。ここに化粧品製造で 培われたマイクロエマルション技術が最大限に活 用されることが期待される。

\section{引用文献}

1) R.L. Juliano, Advanced Drug Delivery Reviews, 2, 31 (1988)

2) 水島, 癌と化学療法, 15, 1077 (1988)

3) Y. Mizushima, J. Pharm. Pharmacol., 38, 132 (1985)

4) Y. Mizushima, Drugs Expt1. Clin. Res., XI (9) 595 (1985)

5）半田, 表面, 30, (4) 325 (1991). PHARM TECH JAPAN, 7, (5) 592 (1991)

6) T. Handa et al., Biochemistry, 29, 2884(1990)

7) 広田, Pharma Medica, 7, (7) 85 (1989)

8) F.Ellouz et al., Biochem. Biophys. Res. Commun., 59, 1317 (1974)

9) S.Kotani et al., Biken J., 18, 105 (1975)

10) T. Brodot et al., Cancer immunol. immunother., 28, 54 (1989)

11) J.E.Talmadge et al., Cancer Res., 46, 1160 (1986)

12）富川他, 日本薬学会108年会要旨集

(1992年 7 月 8 日受理) 